\title{
Impact of temperature stress on secondary metabolite profile and phytotoxicity of Amaranthus cruentus L. leaf extracts
}

\author{
Maria Elizabeth CAWOOD ${ }^{1, *}$, Ingrid ALLEMANN ${ }^{1}$, James ALLEMANN ${ }^{2}$
}

Received May 23, 2018; accepted November 07, 2018.

Delo je prispelo 23. maja 2018, sprejeto 07. novembra 2018.

\begin{abstract}
In this study Amaranthus cruentus plants were grown under controlled optimal conditions $\left(28 / 21^{\circ} \mathrm{C}\right)$ for three months and then subjected to cold $\left(14 / 7{ }^{\circ} \mathrm{C}\right)$ and hot $\left(33 / 40{ }^{\circ} \mathrm{C}\right)$ temperatures. We investigated the influence of these temperature regimes on the metabolite profile of the leaves through analyses of data by TLC, HPLC and GC-MS spectrometry. The phytotoxic potential of a methanol-water (MW) and dichloromethane (DCM) extract from the aerial parts were examined through in vitro screening of germination and growth of lettuce and pepper. The optimal extracts displayed the highest diversity of secondary metabolites, and the highest total phenolics and flavonoids content. Through TLC and HPLC analysis the significantly lower phenolic content in the hot temperature treated samples was confirmed. A wide range of metabolites were detected in the DCM extracts through GC-MS analyses. The phytotoxicity of both the MW and DCM extracts were demonstrated, as germination and growth of pepper and lettuce were significantly inhibited, indicating the presence of more than one allelochemical compound which may affect the allelopathic activity of $A$. cruentus during changes in environmental temperatures.
\end{abstract}

Key words: Amaranthus cruentus; temperature; stress; phytotoxcitiy; metabolites; phenolic compounds
IZVLEČEK

\author{
VPLIV TEMPERATURNEGA STRESA NA PROFIL IN \\ FITOTOKSIČNOST SEKUNDARNIH METABOLITOV \\ V LISTNEM IZVLEČKU ZRNATEGA ŠČIRA \\ (Amaranthus cruentus L.).
}

Rastline zrnatega ščira so bile za namene te raziskave gojene $\mathrm{v}$ nadzorovanih optimalnih temperaturnih razmerah tri mesece $\left(28 / 21^{\circ} \mathrm{C}\right)$ in nato izpostavljene hladu $\left(14 / 7{ }^{\circ} \mathrm{C}\right)$ in vročini $\left(33 / 40{ }^{\circ} \mathrm{C}\right)$. Preučevan je bil vpliv temperaturnih režimov na profil metabolitov v listih ščira z metodami kot so TLC, HPLC in GC-MS spektroskopija. Fitotoksični potencial metanolnovodnih (MW) in diklormetanskih (DCM) izvlečkov nadzemnih delov ščira je bil analizirana preko in vitro analize kalitve vrtne solate in paprike. Optimalni izvlečki so imeli največjo raznolikost sekundarnih metabolitov in največjo vsebnost celokupnih fenolov in flavonoidov. S TLC in HPLC analizo je bila potrjena značilno manjša vsebnost fenolov $\mathrm{v}$ vročinsko obdelanih vzorcih. Z GC-MS analizo je bil ugotovljen širok nabor metabolitov $\mathrm{V}$ diklormetanskih izvlečkih (DCM). Fitotoksičnost MW in DCM izvlečkov se je izrazila $\mathrm{v}$ značilno zmanjšani kalitvi in rasti solate in paprike, kar kaže na prisotnost več kot ene alelokemične spojine. To lahko posledično vpliva na alelopatsko aktivnost zrnatega ščira med spremembami temperature v okolju.

Ključne besede: Amaranthus cruentus; temperatura; stres; fitotoksičnost; metaboliti; fenolne spojine

\section{INTRODUCTION}

Several studies documented on the increase of secondary compounds or changes in chemical profile within specimens of the same plant species growing under different or environmental stress conditions
(Gobbo-Neto \& Lopes, 2007; Ramakrishna \& Ravishankar, 2011; Gouvea et al., 2012). The interaction between plants and their environment influence synthesis and accumulation of secondary

\footnotetext{
1 Department of Plant Sciences, University of the Free State, Bloemfontein, South Africa *Corresponding author: cawoodme@ufs.ac.za

2 Department of Soil, Crop and Climate Sciences, University of the Free State, Bloemfontein, South Africa
}

This article is part of a Master thesis entitled » Influence of abiotic stress on allelopathic properties of Amaranthus cruentus L. «, issued by Ingrid Allemann, Supervisor Dr Maria Elizabeth Cawood, Ph. D., Co-Supervisor Dr James Allemann, Ph.D. 
metabolites and their roles as a response to the environment. (Rhoads et al., 2006). The exposure to various environmental stresses can strengthen the allelopathic potential of many plants (Einhellig, 1987, 1996; Gershenzon, 1984; Tang et al., 1995; Kobayashi, 2004) and can affect allelopathy in at least three ways: 1) the production of allelochemicals by the donor species, 2) their bioavailability and 3) modify the effect of an allelochemical on the target plant (Einhellig, 1996, Trezzi et al., 2016).

Amaranth is one of the few multi-purpose crops which can supply grain as well as tasty leafy vegetables of high nutritional quality (Mensah et al., 2008; Maiyo et al., 2010; Nana et al., 2012; Alemayehu et al., 2015). The chemical constituents and medicinal value of amaranth have been well described in the literature (Stintzing et al., 2004; Steffensen et al., 2011; Kraujalis et al., 2013). Most of the reported compounds include: carotenoids, steroids (Maiyo et al., 2010; Oboh et al.,
2008; Bishop \& Yokoto, 2001), terpenoids (Connick et al., 1989), ascorbic acid, betacyanins (Cai et al., 1998), $\alpha$-spinasterol, spinoside, amaranthoside, amaracine (Shah, 2005), phenolic compounds (Kraujalis et al., 2013) and saponins (Vincken et al., 2007). Some of these compounds are considered to be allelochemicals which are able to affect surrounding plants once released into the environment (Rice, 1984; Waller, 1987). These phytotoxic compounds offer the opportunity to act as natural herbicides, since there is an increasing need for more cost-effective, safer, and more selective herbicides.

This study evaluated the influence of temperature on plant secondary metabolite production of A. cruentus L. and whether the chemical-mediated interaction is involved in A. cruentus allelopathy. Thus, phytotoxcitiy of A. cruentus was evaluated with extracts of the different temperature treatments.

\section{MATERIALS AND METHODS}

\subsection{Plant material}

Amaranthus cruentus 'Anna' seeds were planted in pots containing a soil-compost $(80: 22 \mathrm{v} / \mathrm{v})$ mixture and grown at $28 / 21{ }^{\circ} \mathrm{C}$; day/night temperatures in climate controlled chambers at The Department of Agriculture, University of the Free State as described by Allemann et al. (2017). Vegetable seeds used in this study were obtained from Starke Ayres: 'California Wonder' Sweet Pepper and 'Great Lakes' Lettuce.

\subsection{Crude extracts}

Methanol-water (70:30 v/v) and dichloromethane (DCM) were used as solvents. Ten grams of the powdered A. cruentus leaf material (oven dried at 40 ${ }^{\circ} \mathrm{C}$ ) was extracted twice by shaking overnight in the different solvents $(1: 20 \mathrm{w} / \mathrm{v})$. The pooled extracts were dried and kept at $4{ }^{\circ} \mathrm{C}$ until further analyses.

\subsection{Allelopathy determination}

A combination of the 'sandwich method' of Fujii et al. (2003) and Hill et al. (2007) was used to determine the in vitro phytotoxicity of the crude leaf extracts from the different temperature treatments of A. cruentus on the vegetable seeds. For this method 5 and $20 \mathrm{mg}$ of each extract was dissolved in $1 \mathrm{ml}$ of their own solvent, and 1 $\mathrm{ml}$ pipetted onto a filter paper. The filter papers were allowed to dry then placed on the bottom layer of agar resulting in 0.5 or $2 \mathrm{mg} \mathrm{ml}^{-1}$ extract per well. Controls contain only the solvents on filter paper.
Lettuce (Lactuca sativa L.) and pepper (Capsicum annuит L.) seeds were surface sterilised as described by Allemann et al. (2017) and each of the experiments was done in triplicate and presented as the mean of the replicates.

\subsection{Total phenolic and flavonoid content}

Total phenolic content was evaluated in the methanolic extract, using the Folin-Ciocalteu method as reported by Singleton \& Rossi (1965). The absorption was measured at $550 \mathrm{~nm}$ and the content in phenolics was expressed as mg gallic acid equivalents (GAE) of dry mass extract. Total flavonoid content was determined as reported by Zhishen et al. (1999). The absorption was measured at $510 \mathrm{~nm}$ and the content in flavonoids was expressed as mg quercetin equivalents (QE) of dry mass extract.

\subsection{Thin Layer Chromatography}

Thin layer chromatography (TLC) was carried out using silica gel $60 \mathrm{~F}_{450}$-aluminium backed pre-coated plates. Extracts $\left(50 \mathrm{mg} \mathrm{ml} \mathrm{ml}^{-1}\right)$ were dissolved in their appropriate extraction solvents and $10 \mu \mathrm{l}$ applied to the TLC. The mobile phase for development of the MW extracts was chloroform-methanol-water-acetic acid (65:35:5:1), while for the DCM extracts, plates were developed in toluene-ethyl acetate (93:7). Compounds resolved on the plate were visualized using ultraviolet light (UV) at $365 \mathrm{~nm}$ and $254 \mathrm{~nm}$, ninhydrin (Pifrung, 2006), $p$-anisaldehyde-sulphuric/acetic acid, $5 \%$ ferric chloride and dragendorf reagents, prepared according to 
the standard methods described by Wagner \& Bladt (1996).

\subsection{High Pressure Liquid Chromatography}

The MW extracts $\left(20 \mathrm{mg} \mathrm{ml}^{-1}\right)$ were separated and identified through high pressure liquid chromatography (HPLC) by comparing the retention times to standard phenolic compounds. Standards were prepared in methanol $\left(3 \mathrm{mg} \mathrm{ml}^{-1}\right)$ and absorption measured between 200 and $400 \mathrm{~nm}$. Ten micro litre of extracts and $2 \mu 1$ of standards were injected while the flow rate was kept at 1 $\mathrm{ml} \mathrm{min}{ }^{-1}$. A Shimadzu instrument with a Photo Diode Array Detector (PDA) and an elution procedure as described by Vidović et al. (2015) with a C18 column (Phenomenex $\mathrm{C} 18,250 \mathrm{~mm} \times 4.6 \mathrm{~mm}, 5 \mu \mathrm{m}$ diameter), was used to achieve acceptable separation of all compounds. The mobile phase consisted of: A, acetonitrile and $\mathrm{B}$, a mixture of acetic acid- acetonitrilephosphoric acid-water (10:5:0.1:84:9, by vol.).

\subsection{GC-MS analysis}

The DCM extracts $(10 \mathrm{mg})$ were dissolved in $1 \mathrm{ml}$ hexane. Analyses was done through GC-MS using a
Shimadzu GC-MS QP-2010 gas chromatography equipped with a DB-5 MS column $(30 \mathrm{~m}$ length $\times 0.32$ $\mathrm{mm}$ diameter $\times 0.25 \mu \mathrm{m}$ film thickness) and injecting 1 $\mu 1$ of sample. The GC operating conditions were the following: $5 \mathrm{~min}$ at $60{ }^{\circ} \mathrm{C}$, then gradually increased to $280{ }^{\circ} \mathrm{C}$ at a rate of $2{ }^{\circ} \mathrm{C} \mathrm{min}^{-1}$, and held for $10 \mathrm{~min}$. Helium was used as the carrier gas $\left(1.5 \mathrm{ml} \mathrm{min}^{-1}\right.$ flow rate). Spectra analysis was conducted using the library "National Institute of Standard and Technology (NIST) version 5.0.

\subsection{Statistical analysis}

The experiments were carried out adopting a completely randomized design with three replications. The results were expressed as means with least significant difference (LSD). Analysis of variance (ANOVA) was performed using SAS 9.3 (Institute Inc., Cary, NC, USA, 2008) statistical programme for data and TukeyKramer's LSD procedure for comparison of means. Significance of differences compared to the control groups was determined using the t-test (Steel \& Torrie, 1980).

\section{RESULTS AND DISCUSSION}

\subsection{Metabolites}

Comparison of the compounds in the MW and DCM leaf extracts of the different temperature treatments of A. cruentus plants, are illustrated by TLC in Figure 1. It is clear that temperature played an obvious role in the production of secondary compounds, as clear differences in compounds between the treatments were visible in both the polar and non-polar extracts (Fig. 1A $\& \mathrm{~B})$. Different compounds with varying $\mathrm{R}_{\mathrm{f}}$ values were visible when spraying the TLC's with $p$-anisaldehydesulphuric/acetic acid reagent. Colours of compounds range from green, yellow, pink, blue and purple with different $R_{f}$ values for the polar and non-polar extracts. The diverse coloured compounds with varying $R_{f}$ values visible in both polar and non-polar extracts on TLC (Fig. 1) may indicate many different compounds, including terpenes, saponins, sugars and flavonoids amongst others (Wagner \& Bladt 1996).

In the optimal treatment of the MW extract, 11 compounds were noted, compared to 8 and 5 in the cold and hot treated samples respectively. Prominent spots, including a dark purple $\left(\mathrm{R}_{\mathrm{f}}=0.055\right)$, a blue-purple $\left(\mathrm{R}_{\mathrm{f}}=\right.$ $0.49)$ and a light blue spot $\left(R_{f}=0.6\right)$ were only present in the optimal extract (Fig. 1A). From these results one can deduct that the stress temperatures, particularly the hot, inhibited the biosynthesis of some of the more polar compounds.
Differences were also visible in the non-polar samples (Fig. 2B), with a noticeable blue coloured compound visible at $R_{f}=0.83$, solely in the hot treatment DCM extract (Fig 1B). Less green pigment, probably chlorophyll was also observed in the hot treatment extract, indicating the effect the hot treatment had on photosynthesis.

Several studies were conducted on the impact of increased temperatures on secondary metabolite production of plants (Morrison \& Lawlor, 1999). Phenolic compounds are important and common plant allelochemicals in the ecosystem and the main phenolic compounds are water soluble ( $\mathrm{Li}$ et al., 2010). Kraujalis et al. (2013) reported on the antioxidant properties and phytochemical composition of amaranth extracts isolated by acetone and methanol-water from plant leaves, flowers, stems and seeds. They found that the methanol-water extract of the leaves possessed the highest antioxidant activities and various phenolic compounds and flavonoids e.g. rutin, nicotiflorin, isoquercitrin, 4-hydroxybenzoic and p-coumaric acids were identified as major constituents. In the review article by Mroczek (2015) it is reported that saponins were isolated from a diversity of Amaranthaceae genera and species. 


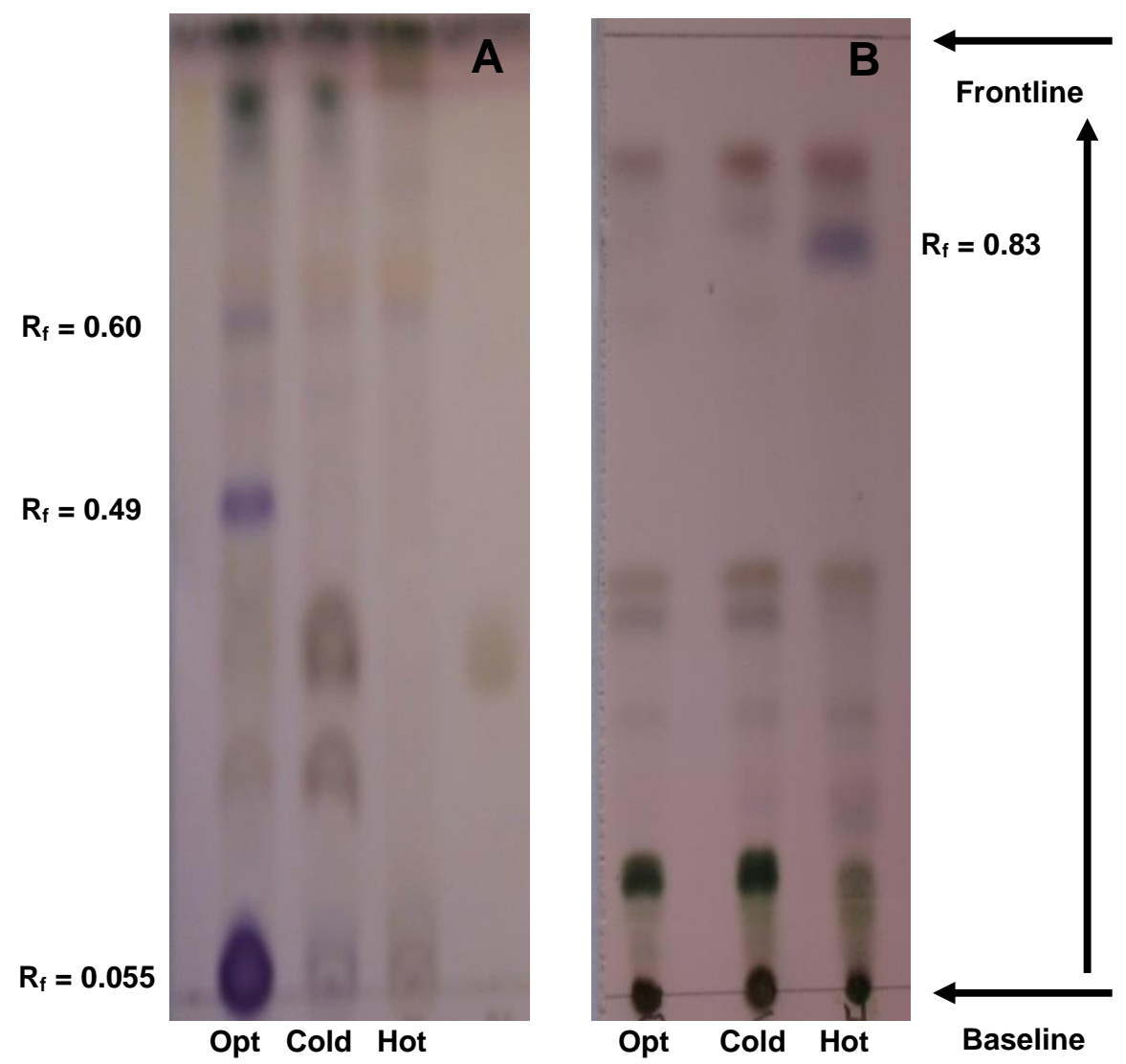

Figure 1: Qualitative TLC profiles of the optimal, cold and hot treated A. cruentus MW (A) and DCM (B) leaf extracts. Detection by $p$-anisaldehyde reagent

In this study, the total phenolic and flavonoid content significantly declined in A. cruentus plants exposed to hot temperatures compared to plants grown at the optimal temperature (Table 1). The decrease in total phenolic and flavonoid content are in contrast with findings of many authors who reported an increase in production of phytotoxic phenolic compounds in plant tissues exposed to high temperatures and solar radiation (Koeppe et al., 1969; Wender, 1970; Einhelig \&
Eckrich, 1984). Rudikovskaya et al. (2008), however reported that low growth temperature decreased the content of some phenolic compounds in pea seedling roots and according to Król et al. (2014), long-term drought stress caused a decrease in particular components of secondary metabolism in the leaves and roots of grapevine. It seems therefore that one cannot expect generalized patterns of phenolic compounds in stress situations.

Table 1: Total phenolic and flavonoid compounds in temperature stressed amaranth leaf material

\begin{tabular}{ccc}
\hline Treatment & $\begin{array}{c}\text { Total phenolic content (mg GAE } \\
\text { g D.M }\end{array}$ & $\begin{array}{c}\text { Total flavonoid content }(\mathrm{mg} \mathrm{QE} \mathrm{g} \\
\left.\text { D.M }^{-1} \text {. }\right)\end{array}$ \\
\hline Cold & $12.0 \mathrm{~b}$ & $5.4 \mathrm{a}$ \\
Optimal & $18.8 \mathrm{a}$ & $5.6 \mathrm{a}$ \\
Hot & $10.1 \mathrm{~b}$ & $4.1 \mathrm{~b}$ \\
\hline
\end{tabular}


Analyses by HPLC confirmed the decrease in phenolic compounds in the temperature stressed plants (Fig 2).

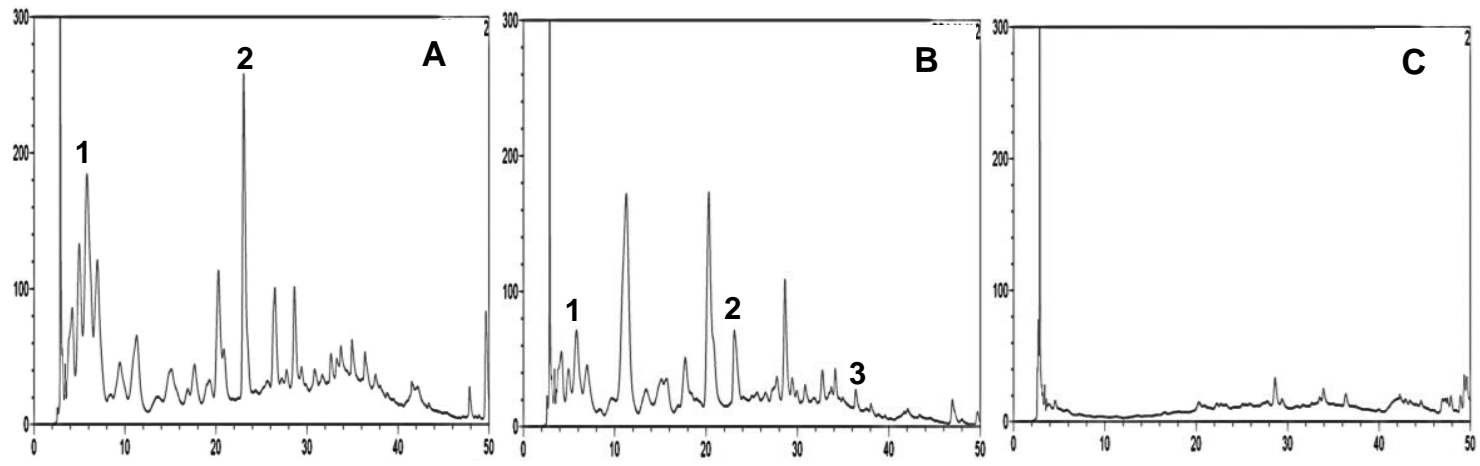

Figure 2: Comparison of HPLC-PDA chromatograms of optimal (A), cold (B) and hot (C) temperature treated $A$. cruentus methanol-water leaf extracts. $1=$ Catechin; 2 = Rutin; $3=$ Quercetin

Flavonoids are not usually seen as allelopathic compounds but they have other roles in plants such as attractants to pollinators, protection against ultraviolet light (Li et al., 1993) and as an anti-inflammatory, antiallergic and anti-viral activities (Miller, 1996). Some flavonoids do however have allelopathic properties such as quercetin (Inderjit \& Dakshini, 1995), catechin (Bais $\&$ Kaushik, 2010; Chobot et al., 2009) and rutin (Basile et al., 2000), which has been found in both A. hybridus and A. cruentus. From our HPLC results, catechin and rutin were identified in the optimal and cold treated amaranth MW leaf litter extracts (Fig 2A \& B), while a small amount of quercetin was detected in only the cold treated sample (Fig 2B). The heat treated sample contained a reduced amount of unidentified compounds (Fig 2C), indicating the role temperature play on the biosynthesis of flavonoids and the possible consequence on allelopathy.

The influence of temperature on the expressed compounds in the different DCM extracts were clearly visible after analyses through gas chromatography and mass spectrometry (GC-MS). Major compounds made up a total composition of $75.69 \%$ (9 compounds), $90.44 \%$ (7 compounds) and $91.89 \%$ (9 compounds), of the optimal, cold and heat treated samples respectively (Table 2). Neophytadiene and hexadecanoic acid were the only compounds present in all three extracts, although the concentrations of these compounds varied substantially between the treatments (Table 2). The highest concentration of neophytadiene $(27.53 \%)$ was found in the cold treated sample, while hexadecanoic acid $(13.52 \%)$ was maximum in the heat treatment extract. Squalene, trans-phytol and the phytosterol, stigmasta-7,22-dien-3-ol were present in only cold and heat treated samples.

Gamel et al. (2007) found high squalene concentrations in oil fractions of A. caudatus L. and A. cruentus, while Shah (2005) reported on the presence of stigmasta-7,22dien-3-ol ( $\alpha$-spinasterol) in A. spinosus $\mathrm{L}$.. According to Szakiel et al. (2010), lower soil temperatures triggered an increase in levels of steroidal furostanol and spirostanol saponins. 
Table 2: GC-MS results of compounds present in optimal, cold and hot temperature treated DCM leaf extracts of $A$. cruentus

\begin{tabular}{|c|c|c|c|c|}
\hline $\begin{array}{l}\text { Retention } \\
\text { time (min) }\end{array}$ & Compound name* & $\begin{array}{l}\text { Optimal } \\
\text { area } \%\end{array}$ & $\begin{array}{c}\text { Cold } \\
\text { area } \%\end{array}$ & $\begin{array}{c}\text { Hot } \\
\text { area } \%\end{array}$ \\
\hline 63.315 & 16-Heptadecenal & 13.22 & - & - \\
\hline 64.054 & Neophytadiene & 9.03 & 30.70 & 4.44 \\
\hline 65.296 & $\begin{array}{l}\text { 3,7,11,15-Tetramethyl-2- } \\
\text { hexadecen-1-ol }\end{array}$ & - & 5.19 & 3.72 \\
\hline 66.193 & trans-Phytol & - & 10.04 & 6.01 \\
\hline 70.621 & Hexadecanoic acid (Palmitic acid) & 11.01 & 3.29 & 13.52 \\
\hline 77.243 & $\begin{array}{l}\text { 2-Hexadecen-1-ol, 3,7,11,15- } \\
\text { tetramethyl }\end{array}$ & - & - & 7.82 \\
\hline 78.458 & $\begin{array}{c}9,12,15 \text {-Octadecatrienoic acid ( } \alpha \text { - } \\
\text { Linolenic acid) }\end{array}$ & - & 27.40 & 29.68 \\
\hline 79.695 & Octadecanoic acid (Stearic acid) & - & - & 2.30 \\
\hline 81.156 & $\begin{array}{l}\text { Tetrahydrofurano[6a,7a-b]-5-oxa-8- } \\
\text { thiaphenanthrene }\end{array}$ & 9.86 & - & - \\
\hline 97.733 & Hexahydrothunbergol & 7.07 & - & - \\
\hline 102.751 & bis-Naphthylfuran & 5.47 & - & - \\
\hline 103.841 & Methyl ester of decyclotrenudine & 5.02 & - & - \\
\hline 103.992 & (-)-18-Noramborx & 4.84 & - & - \\
\hline 104.067 & Benzyl methyl ether & 10.17 & - & - \\
\hline 104.920 & Squalene & - & 3.73 & 6.22 \\
\hline 121.002 & $\begin{array}{l}\text { Stigmasta-7,22-dien-3-ol ( } \alpha \text { - } \\
\text { Spinasterol) }\end{array}$ & - & 10.09 & 12.36 \\
\hline Total & & 75.69 & 90.44 & 91.89 \\
\hline
\end{tabular}

Area $(\%)$ of compound $=$ height of peak $\mathrm{x}$ width of peak at $1 / 2$ height $\leq \mathrm{x}$ Total area

* Identification by Library: NIST 05. LIB

\subsection{Phytotoxcitiy}

Germination

Phytotoxic activity of A. cruentus extracts may be ascribed to a wide range of biologically active phytochemicals such as phenolic acids, flavonoids and fatty acids which are known for their phytotoxic and allelochemical activities. When these compounds are released into the soil by leaf litter decomposition there may be a change in both the physical and chemical properties and therefore affecting the organization and growth of plant communities. At different concentrations both the MW and DCM extracts of the different temperature treatments, significantly inhibited germination of both lettuce and pepper $\left(\operatorname{LSD}_{(\mathrm{T} \leq 0.05)}=\right.$ 1.88) (Table 3). The polar MW extract was more effective in lowering germination percentages in both pepper and lettuce than the non-polar DCM extract (Table 3). 
Impact of temperature stress on secondary metabolite profile and phytotoxicity of Amaranthus cruentus L. leaf extracts

Table 3: Germination percentage of pepper and lettuce seeds exposed to increasing concentrations of $\mathrm{MeOH}-\mathrm{H}_{2} \mathrm{O}$

\begin{tabular}{lllll}
\hline \multirow{2}{*}{$\begin{array}{l}\text { Extract } \\
{\left[\mathrm{mg} \mathrm{ml}^{-1}\right]}\end{array}$} & \multicolumn{4}{l}{ Germination \% of pepper } \\
\cline { 2 - 5 } MW & Optimal & Cold & Hot & Ave \\
\hline 0 & 100 & 100 & 100 & 100 \\
0.5 & 29 & 24 & 29 & 27 \\
2 & 29 & 24 & 33 & 28 \\
Ave & 52 & 49 & 54 & \\
DCM & & & & \\
\hline 0 & 100 & 100 & 100 & 100 \\
0.5 & 49 & 29 & 56 & 44 \\
2 & 40 & 22 & 47 & 36 \\
\hline Ave & 63 & 50 & 68 & \\
\hline $\mathrm{LD}_{(\mathrm{T} \leq 0.05)}=1.88 . \mathrm{n}=96$ & & &
\end{tabular}

\begin{tabular}{lllll}
\hline \multirow{2}{*}{$\begin{array}{l}\text { Extract } \\
{\left[\mathrm{mg} \mathrm{ml}^{-1}\right]}\end{array}$} & \multicolumn{4}{l}{ Germination \% of lettuce } \\
\cline { 2 - 5 } MW & Optimal & Cold & Hot & Ave \\
\hline 0 & 100 & 100 & 100 & 100 \\
0.5 & 24 & 29 & 31 & 28 \\
2 & 24 & 24 & 36 & 28 \\
Ave & 49 & 51 & 56 & \\
DCM & & & & \\
0 & 100 & 100 & 100 & 100 \\
0.5 & 69 & 67 & 42 & 59 \\
2 & 42 & 24 & 36 & 34 \\
\hline Ave & 70 & 64 & 59 & \\
\hline
\end{tabular}

Growth

Both the hypocotyl and seminal root were significantly inhibited when exposed to extracts of all the temperature treatments, however the cold stress treatment was the most detrimental (Table $4 \& 5$ ). The results also confirmed that root elongation was more sensitive to allelochemicals than stem (hypocotyl) elongation in both species. Furthermore, both polar and non-polar extracts, at 0.5 and $2 \mathrm{mg} \mathrm{ml}^{-1}$, significantly reduced the growth of lettuce (Table 4) and pepper (Table 5). Allelopathy influences plant succession through root exudation, leaching and volatilization when the plant dies and starts to decompose (Rice 1984; Weston 2005; Minorsky 2002; Bertin et al. 2003). The most frequently reported morphological effects from allelochemicals on sensitive plants is the inhibition or retarded seed germination and retarded development of shoots and roots (Ghafarbi et al. 2012). It has been cited in literature that allelopathy was involved in many natural and manipulated ecosystems and that they play a role in the evolution of different plant communities (Ding et al., 2007). Abiotic stresses can lead to morphological, physiological, biochemical and molecular changes within the plants, and therefore has an impact on plant growth (Wang et al., 2003). Climate change and temperature play a role in the synthesis of

allelochemicals, which can affect the growth processes of neighbouring plants ( $\mathrm{Li}$ et al., 2010). Results by Amini $(2009,2012)$, proved that root exudates of $A$. retroflexus had inhibitory effects on shoot length of both crop (wheat) and vegetable (common bean) plants. Aqueous extracts from the leaves, roots and stems of $A$. retroflexus $\mathrm{L}$. had inhibitory effects on the hypocotyl growth of maize (Konstantinović et al., 2014). Dhole et al. (2013) noticed that seed germination and seedling growth of maize were inhibited when using aqueous extracts from the root, stems and leaves of A. tricolor L..

Phenolic compounds take part in the regulation of seed germination and work together in regulating the growth of plants. The role of several phenolic compounds e.g. lignin, salicylic acid, flavonoids and phytoalexins play important roles in plant resistance, taking part in defence responses during biotic and abiotic stress (Kulbat, 2016). It is therefore possible that the reduction in phenolic compounds caused by temperature stress, could play a role in the germination and growth of lettuce and pepper seeds. Furthermore, it is clear from both literature and our results, that concentration plays a major role in the severity of allelopathic effects on different plants (Qasem, 1995; Obaid \& Qasem, 2005). 
Maria Elizabeth CAWOOD et al.

Table 4: Hypocotyl and seminal root lengths of lettuce seeds exposed to increasing concentrations of $\mathrm{MeOH}_{-} \mathrm{H}_{2} \mathrm{O}$ and DCM leaf extracts of $A$. cruentus grown at optimal, cold and hot temperatures

\begin{tabular}{|c|c|c|c|c|c|c|c|c|}
\hline $\begin{array}{c}\text { Extract } \\
{\left[\mathrm{mg} \mathrm{ml}^{-1}\right]}\end{array}$ & \multicolumn{4}{|c|}{ Hypocotyl length of Lettuce (mm) } & \multicolumn{4}{|c|}{ Seminal root length of Lettuce (mm) } \\
\hline \multirow{2}{*}{$\begin{array}{c}\mathrm{MeOH}- \\
\mathrm{H}_{2} \mathrm{O}\end{array}$} & \multicolumn{4}{|c|}{ Temperature treatment } & \multicolumn{4}{|c|}{ Temperature treatment } \\
\hline & Optimal & Cold & Hot & Ave & Optimal & Cold & Hot & Ave \\
\hline 0 & $28.77 \pm 9.07$ & $28.77 \pm 9.07$ & $28.77 \pm 9.07$ & $28.77 \mathrm{a}$ & $26.31 \pm 11.2$ & $26.31 \pm 11.2$ & $26.31 \pm 11.2$ & $26.31 \mathrm{a}$ \\
\hline 0.5 & $26.77 \pm 16.5$ & $29.15 \pm 17.8$ & $31.69 \pm 11.4$ & $29.03 \mathrm{a}$ & $17.54 \pm 12.5$ & $13.23 \pm 7.25$ & $15.08 \pm 6.45$ & $15.28 \mathrm{~b}$ \\
\hline 2 & $20.62 \pm 12.8$ & $6.31 \pm 9.46$ & $13.08 \pm 7.99$ & $13.34 \mathrm{~b}$ & $8 \pm 7.43$ & $3.15 \pm 3.31$ & $3.85 \pm 2.44$ & $5 \mathrm{c}$ \\
\hline Ave & 25.39 & 21.41 & 24.51 & & 17.28 & 14.23 & 15.08 & \\
\hline $\operatorname{LSD}_{(\mathrm{T} \leq 0.05)}$ & $\mathrm{T}=\mathrm{ns}$ & $\mathrm{C}=.23$ & $\mathrm{~T} \times \mathrm{C}=$ & & $\mathrm{T}=\mathrm{ns}$ & $\mathrm{C}=.39$ & $\mathrm{~T} \times \mathrm{C}=\mathrm{ns}$ & \\
\hline \multicolumn{9}{|l|}{ DCM } \\
\hline 0 & $35.48 \pm 11.7$ & $35.48 \pm 11.7$ & $35.48 \pm 11.7$ & $35.48 \mathrm{a}$ & $27.63 \pm 12.4$ & $27.63 \pm 12.1$ & $27.62 \pm 11.8$ & $27.63 \mathrm{a}$ \\
\hline 0.5 & $28.85 \pm 6.27$ & $17.31 \pm 9.29$ & $9.77 \pm 4.64$ & $18.64 \mathrm{~b}$ & $19.62 \pm 5.04$ & $15.77 \pm 9.49$ & $8 \pm 4.16$ & $14.46 \mathrm{~b}$ \\
\hline 2 & $26.77 \pm 7.93$ & $7.08 \pm 8.75$ & $25.38 \pm 7.79$ & $19.74 b$ & $14.08 \pm 5.99$ & $9.08 \pm 8.84$ & $16.69 \pm 6.71$ & $13.28 \mathrm{~b}$ \\
\hline Ave & 29.79 & 20.54 & 23.54 & & 19.49 & 17.82 & 17.44 & \\
\hline $\begin{array}{c}\mathrm{LSD}_{(\mathrm{T}} \leq \\
0.05)\end{array}$ & $\mathrm{T}=4.89$ & $C=4.89$ & $\begin{array}{c}\mathrm{T} \times \mathrm{C}= \\
4.89\end{array}$ & & $\mathrm{~T}=\mathrm{ns}$ & $C=.66$ & $\begin{array}{c}\mathrm{T} \times \mathrm{C}= \\
4.66\end{array}$ & \\
\hline
\end{tabular}

Different letters along the column indicate significant differences at $\mathrm{T} \leq 0.05$ (Tukey test). Significant differences within each vegetable; $n=13$.

Table 5: Hypocotyl and seminal root lengths of pepper seeds exposed to increasing concentrations of $\mathrm{MeOH}-\mathrm{H}_{2} \mathrm{O}$ and DCM leaf extracts of $A$. cruentus grown at optimal, cold and hot temperatures

\begin{tabular}{|c|c|c|c|c|c|c|c|c|}
\hline $\begin{array}{c}\text { Extract } \\
{\left[\mathrm{mg} \mathrm{ml}^{-1}\right]}\end{array}$ & \multicolumn{4}{|c|}{ Hypocotyl length of pepper (mm) } & \multicolumn{4}{|c|}{ Seminal root length of pepper (mm) } \\
\hline \multirow{2}{*}{$\begin{array}{c}\mathrm{MeOH}- \\
\mathrm{H}_{2} \mathrm{O}\end{array}$} & \multicolumn{4}{|c|}{ Temperature treatment } & \multicolumn{4}{|c|}{ Temperature treatment } \\
\hline & Optimal & Cold & Hot & Ave & Optimal & Cold & Hot & Ave \\
\hline 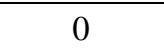 & $20.23 \pm 15.3$ & $20.23 \pm 15.3$ & $20.23 \pm 15.3$ & $20.23 \mathrm{a}$ & $13.92 \pm 5.02$ & $13.92 \pm 5.02$ & $13.92 \pm 5.02$ & $13.92 \mathrm{a}$ \\
\hline 0.5 & $2.69 \pm 4.55$ & $5.62 \pm 3.91$ & $11.31 \pm 7.78$ & $6.54 \mathrm{~b}$ & $1.15 \pm 2.54$ & $3.31 \pm 3.28$ & $9.85 \pm 8.71$ & $4.77 \mathrm{~b}$ \\
\hline 2 & $1.08 \pm 1.80$ & $3.46 \pm 2.26$ & $5.15 \pm 1.99$ & $3.23 \mathrm{~b}$ & $0.46 \pm 0.88$ & $1.08 \pm 0.76$ & $3.46 \pm 4.74$ & $1.67 \mathrm{c}$ \\
\hline Ave & 8 & 9.77 & 12.23 & & 5.18 & 6.10 & 9.08 & \\
\hline $\mathrm{LSD}_{(\mathrm{T} \leq 0.05)}$ & $\mathrm{T}=\mathrm{ns}$ & $C=4.35$ & $\mathrm{~T} \times \mathrm{C}=\mathrm{ns}$ & & $\mathrm{T}=2.29$ & $\mathrm{C}=2.29$ & $\mathrm{~T} \times \mathrm{C}=2.29$ & \\
\hline \multicolumn{9}{|l|}{ DCM } \\
\hline 0 & $16.08 \pm 6.21$ & $16.08 \pm 6.21$ & $16.08 \pm 6.21$ & $16.08 \mathrm{a}$ & $24.38 \pm 11.4$ & $24.38 \pm 11.4$ & $24.38 \pm 11.4$ & $24.38 \mathrm{a}$ \\
\hline 0.5 & $6.31 \pm 2.56$ & $4.31 \pm 5.75$ & $2.46 \pm 1.61$ & $4.36 \mathrm{~b}$ & $12.77 \pm 3.68$ & $2.85 \pm 3.74$ & $1.92 \pm 0.86$ & $5.85 \mathrm{~b}$ \\
\hline 2 & $3.69 \pm 2.66$ & $4.31 \pm 5.02$ & $8.77 \pm 7.33$ & $5.59 \mathrm{~b}$ & $5 \pm 5.74$ & $6.46 \pm 8.90$ & $5.85 \pm 6.01$ & $5.77 \mathrm{~b}$ \\
\hline Ave & 8.69 & 8.23 & 9.10 & & 14.05 & 11.23 & 10.72 & \\
\hline $\begin{array}{c}\mathrm{LSD}_{(\mathrm{T}} \leq \\
0.05)\end{array}$ & $\mathrm{T}=\mathrm{ns}$ & $\mathrm{C}=2.78$ & $\begin{array}{c}\mathrm{T} \times \mathrm{C}= \\
2.78\end{array}$ & & $\mathrm{~T}=\mathrm{ns}$ & $\mathrm{C}=3.87$ & $\begin{array}{c}\mathrm{T} \times \mathrm{C}= \\
3.87\end{array}$ & \\
\hline
\end{tabular}

Different letters along the column indicate significant differences at $\mathrm{T} \leq 0.05$ (Tukey test). Significant differences within each vegetable; $n=13$.

Many studies have been done on allelopathy of the polar extracts of amaranth, but no information is available on the non-polar compounds. This is the first report on the in vitro phytotoxicity of a DCM extract of grain amaranth. The characteristics of allelochemicals are important and play a significant role in their fate in the environment. For example, the mobility of compounds within the soil are influenced by their water solubility; the vapour pressure can impact their volatilization and their chemical structure can affect their affinity with the 
soil surface (Souza Filho \& Alves 2002). The outcome of all these complex interactions results in compounds with allelopathic properties which can be of potential agronomic use.

\section{CONCLUSION}

Temperature influenced the chemical composition of $A$. cruentus and in vitro bioassays proved the negative impact of the extracts on germination and growth of vegetables. This demonstrated that the environment for the cultivation of $A$. cruentus is important and that more than one compound were responsible for allelopathy, thus both polar and non-polar compounds were involved. Furthermore, with increased concentrations of extracts a decrease in germination and seedling development occurred. Consequently, if more plant residues are left behind in the soil, the growth of the next crop will often be affected with a subsequent decline in yield. It was also clear that vegetables displayed diversity in reaction towards the temperature treatments and type of extract. This information proves that a holistic understanding of the influence of abiotic environmental factors on the production of metabolites in various plant parts are of importance. The release of potentially phytotoxic compounds from $A$. cruentus leaf litter into soil deserves further investigation as well as the purification of extracts to determine unidentified natural compounds with herbicidal activity.

\section{REFERENCES}

Allemann, I., Cawood, M.E., Allemann, J. (2017). Influence of altered temperatures on allelopatic properties of Amaranthus cruentus L. Acta agriculturae Slovenica, 109(2), 465-471. doi:10.14720/aas.2017.109.2.29

Alemayehu, F.R., Bendevis, M.A., Jacobsen, S.E. (2015). The potential for utilizing the seed crop Amaranth (Amaranthus spp.) in East Africa as an alternative crop to support food security and climate change mitigation. Journal of Agronomy and Crop Science, 201, 321-329. doi:10.1111/jac.12108

Amini, R., An, M., Pratley, J., Azimi, S. (2009). Allelopathic assessment of annual ryegrass (Lolium rigidum): Bioassays. Allelopathy Journal, 24(1), 67-79.

Amini, R., Movahedpour, F., Ghassemi-Golezani, K., Mohammadi-Nasab, A.D., Zafarani-Moattar, P. (2012). Allelopathic assessment of common amaranth by ECAM. International Research Journal of Applied \& Basic Sciences, 3(11), 2268-2272.

Bais, H.P., Kaushik, S. (2010). Catechin secretion \& phytotoxicity. Communicative \& integrative Biology, 3(5), 468-470. doi:10.4161/cib.3.5.12559

Basile, A., Sorbo, S., Giordano, S., Ricciardi, L., Ferrara, S., Montesano, D., Cobianchi, R.C., Vuotto, M.L., Ferrara, L. (2000). Antibacterial and allelopathic activity of extract from Castanea sativa leaves. Fitoterapia 7, Suppl., S110-S116. doi:10.1016/S0367-326X(00)00185-4

Bertin, C., Yang, X., Weston, L.A. (2003). The role of root exudates and allelochemicals in the rhizosphere. Plant and Soil, 256, 67-83. doi:10.1023/A:1026290508166

Bishop, G.J., Yokota, T. (2001). Plants steroid hormones, brassinosteroids: current highlights of molecular aspects on their synthesis/metabolism, transport, perception and response. Plant and Cell Physiology, 42(2), doi:10.1093/pcp/pce018

Cai, Y., Sun, M., Corke, H. (1998). Colorant properties and stability of Amaranthus betacyanin pigments. Journal of Agricultural and Food Chemistry, 46(11), 4491-4495. doi:10.1021/jf980457g

Chobot, V., Huber, C., Trettenhahn, G., Hadacek, F. (2009). ( \pm )-Catechin: Chemical weapon, antioxidant, or stress regulator? Journal of Chemical Ecology, 35(8), 980-996. doi:10.1007/s10886-009-9681-x

Connick, W.J., Bradow, J.M., Legendre, M.G. (1989). Identification and bioactivity of volatile allelochemicals from Amaranth residues. Journal of Agricultural and Food Chemistry, 37, 792-796. doi:10.1021/jf00087a049

Dhole, J.A., Lone, K.D., Dhole, G.A., Bodke, S.S. (2013). Allelopathic effect of aqueous and ethanolic extracts of some common weeds on seed health of Triticum aestivum L. (Wheat). International Journal of Current Microbiology and Applied Sciences, 2(6), 254-260.

Ding, J., Sun, Y., Xiao, C.L., Shi, K., Zhou, Y.H., Yu, J.Q. (2007). Physiological basis of different allelopathic reactions of cucumber and fig leaf gourd plants to cinnamic acid. Journal of 
Experimental Botany, 58(13), 3765-3773. doi:10.1093/jxb/erm227

Einhellig, F.A., Eckrich, P.C. (1984). Interactions of temperature and ferulic acid stress on grain sorghum and soybeans. Journal of Chemical Ecology, 10, 161-170. doi:10.1007/BF00987653

Einhellig, F.A. (1987). Interactions among allelochemicals and other stress factors of the plant environment. ACS Symposium Series, 330, 343357. doi:10.1021/bk-1987-0330.ch032

Einhellig, F.A. (1996). Interactions involving allelopathy in cropping system. Agronomy Journal, 88 , 886-893. doi:10.2134/agronj1996.00021962003600060007x

Fujii, Y., Parvez, S.S., Parvez, M.M., Ohmae, Y., Iida, O. (2003). Screening of 239 medical plant species for allelopathic activity using the sandwich method. Weed Biology and Management, 3, 233-241. doi:10.1046/j.1444-6162.2003.00111.x

Gamel, T.H., Mesallam, A.S., Damir, A.A, Shekib, L.A, Linssen, J.P. (2007). Characterization of Amaranth seed oils. Journal of Food Lipids, 14, 323-334. doi:10.1111/j.1745-4522.2007.00089.x

Gershenzon, J. (1984). Changes in the levels of plant secondary metabolites under water and nutrient stress. Recent Advances in Phytochemistry, 18, 273-320. doi:10.1007/978-1-4684-1206-2_10

Ghafarbi, S.P., Hassannejad, S., Lotfi, R. (2012). Allelopathic effects of wheat seed extracts on seed and seedling growth of eight selected weed species. International Journal of Agricultural Research, 4(19), 1452-1457.

Gobbo-Neto, L., Lopes, N.P. (2007). Medicinal plants: factors of influence on the content of secondary metabolites. Quimica Nova, 30(2), 374-381. doi:10.1590/S0100-40422007000200026

Gouvea, D.R., Meloni, F., Ribeiro, A.B.B., Lopes, J.L.C., Lopes, N.P. (2012). A new HPLC-DADMS/MS method for the simultaneous determination of major compounds in the crude extract of Lychnophora salicifolia Mart. (Brazilian arnicõo) leaves: Application of chemical variability evaluation. Analytica Chimica Acta, 748, 28-36. doi:10.1016/j.aca.2012.08.027

Hill, E.C., Ngouajio, M., Nair, M.G. (2007). Allelopathic potential of hairt vetch (Vicia villosa) and cowpea (Vigna unguiculata) methanol and ethyl acetate extracts on weeds and vegetables. Weed Technology, 21, 437-444. doi:10.1614/WT06-167.1
Inderjit, A.U., Dakshini, K.M.M. (1995). On laboratory bioassays in allelopathy. The Botanical Review, 61, 28-44. doi:10.1007/BF02897150

Kobayashi, K. (2004). Factors affecting phytotoxic activity of allelochemicals in soil. Weed Biology and Management, 4, 1-7. doi:10.1111/j.14456664.2003.00112.x

Koeppe, P.E., Rohrbaugh, L.M., Wender, S.H. (1969). The effect of varying UV intensities on the concentration of scopolin and caffeoylquinic acids in tobacco and sunflower. Phytochemistry, 8, 889896. doi:10.1016/S0031-9422(00)85879-3

Konstantinović, B., Blagojević, M., Konstantinivić, B., Samardžić, N. (2014). Allelopathic effect of weed species Amaranthus retroflexus L. on maize seed germination. Romanian Agricultural Research, 31, 315-321.

Kraujalis, P., Venskutonis, P.R., Kraujaliene, V., Pukalskas, A. (2013). Antioxidant properties and preliminary evaluation of phytochemical composition of different anatomical parts of Amaranth. Plant Foods for Human Nutrition, 68, 322-328. doi:10.1007/s11130-013-0375-8

Król, A., Amarowicz, R., Weidner, S. (2014). Changes in the composition of phenolic compounds and antioxidant properties of grapevine roots and leaves (Vitis vinifera L.) under continuous of long-term drought stress. Acta Physiologiae Plantarum, 36, 1491-1499. doi:10.1007/s11738-014-1526-8

Kulbat, K. (2016). The role of phenolic compounds in plant resistance. Biotechnology and Food Sciences, 80(2), 97-108.

Li, J., Ou-Lee, T.M., Raba, R., Amundsom, R.G., Last, R.L. (1993). Arabidopsis flavonoid mutants are hypersensitive to UV-B irradiation. The Plant Cell, 5(2), 171-179. doi:10.1105/tpc.5.2.171

Li, Z-H., Wang, O., Xiao, R., Cun, D.P., Jiang, D-A. (2010). Phenolics and plant allelopathy. Molecules, 15, 8933-8952. doi:10.3390/molecules15128933

Maiyo, Z.C., Ngure, R.M., Matasyoh, J.C., Chepkorir, R. (2010). Phytochemical constituents and antimicrobial activity of leaf extracts of three Amaranthus plant species. African Journal of. Biotechnology, 9(21), 3178-3182.

Mensah, J.K., Okoli, R.I., Ohaju-Obodo, J.O., Eifediyi, K. (2008). Phytochemical, nutritional and medical properties of some leafy vegetables consumed by Edo people of Nigeria. African Journal of. Biotechnology, 7(14), 2304-2309. 
Impact of temperature stress on secondary metabolite profile and phytotoxicity of Amaranthus cruentus L. leaf extracts

Miller, A.L. (1996). Antioxidant flavonoids: structure, function and clinical usage. Alternative Medicine Review, 1(2), 103-111.

Minorsky, V. (2002). Allelopathy and grain crop production. Plant Physiology, 130, 1745-1746. doi:10.1104/pp.900057

Morrison, J.I.L., Lawlor, D.W. (1999). Interactions between increasing $\mathrm{CO}_{2}$ concentration and temperature on plant growth. Plant, Cell \& Environment, 22, 659-82. doi:10.1046/j.13653040.1999.00443.x

Mroczek, A. (2015). Phytochemistry and bioactivity of triterpene saponins from Amaranthaceae family. Phytochemistry Reviews, 14, 577-605. doi:10.1007/s11101-015-9394-4

Nana, F.W., Hilou, A., Millogo, J.F., Nacoulma, O.G. (2012). Phytochemical composition, antioxidant and xanthine oxidase inhibitory activities of Amaranthus cruentus L. and Amaranthus hybridus L. extracts. Pharmaceuticals, 5(6), 613-628. doi:10.3390/ph5060613

Obaid, K.A., Qasem, J.R. (2005). Allelopathic activity of common weed species on vegetable crops grown in Jordan. Allelopathy Journal, 15(2), 221-236.

Oboh, G., Raddatz, H., Henle, T. (2008). Antioxidant properties of polar and non-polar extracts of some tropical green leafy vegetables. Journal of the Science of Food and Agriculture, 88, 2486-2492. doi:10.1002/jsfa.3367

Qasem, J.R. (1995). The allelopathic effect of three Amaranthus spp. (pigweeds) on wheat (Triticum durum). Weed Research, 35(1), 41-49. doi:10.1111/j.1365-3180.1995.tb02015.x

Pifrung, M.C. (2006). The Synthetic Chemists Companion. Wiley. Online Library. http//www.onlinelibrary.wiley.com/book/10.1002/9 780470141045 (15/09/2013).

Ramakrishna, A., Ravishankar, G.A. (2011). Influence of abiotic stress signals on secondary metabolites in plants. Plant Signaling \& Behavior, 6(11), 17201731. doi:10.4161/psb.6.11.17613

Rhoads, D.M., Umbach, A.L., Subbaiah, C.C., Siedow, J.N. (2006). Mitochondrial reactive oxygen species. Contribution to oxidative stress and interorganellar signaling. Plant Physiology, 141, 357-366. doi:10.1104/pp.106.079129

Rice, E.L. (1984). Allelopathy. 2nd ed. Orlando, Florida, USA: Academic Press; p. 67-68.

Rudikovskaya, E.G., Fedorova, G.A., Dudareva, L.V., Makarova, L.E., Rudikovskii, A.V. (2008). Effect of growth temperature on the composition of phenols in pea roots. Russian Journal of Plant Physiology, 55(5), $712-715$ doi:10.1134/S1021443708050178

Shah, A.H.A. (2005). Spinoside, new coumaroyl flavone glycoside from Amaranthus spinosus. Archives of Pharmacal Research, 27(12), 12161219.

Singleton, V.L., Rossi, Jr J.A. (1965). Colorimetry of total phenolics with phosphomolybdic phosphotungstic acid reagents. American Journal of Enology and Viticulture, 16, 144-158.

Souza Filho, A.P.S., Alves, S.M. (2002). Allelopathy: Basic principles and general aspects. EMBRAPA Amazônia Oriental: Belém, Brazil, p. 206.

Steel, R.G.D., Torrie, J.H. (1980). Principles and procedures of statistics, 2nd ed. New York: McGraw-Hill; p. 633.

Steffensen, S.K., Rinnan, Å., Mortensen, A.G., Laursen, B., de Troiani, R.M., Noellemeyer, E.J., Janovska, D., Dusek, K., Délano-Frier, J., Taberner, A., et al. (2011). Variations in the polyphenol content of seeds of field grown Amaranthus genotypes. Food Chemistry, 129, 131-138. doi:10.1016/j.foodchem.2011.04.044

Stintzing, F.C., Carle, R. (2004). Functional properties of anthocyanins and betalains in plants, food, and in human nutrition. Trends in Food Science \& Technology, 15, 19-38. doi:10.1016/j.tifs.2003.07.004

Szakiel, A., Paczkowski, C., Henry, M. (2010). Influence of environmental abiotic factors on the content of saponins in plants. Phytochemistry Reviews, 10, 471-491. doi:10.1007/s11101-0109177-x

Tang, C-H., Cai, W-F., Kohl, K., Nishimote, R.K. (1995). Plant stress and allelopathy. In: Inderjit AU, Dakshini KMM, Einhellig FA, editors. Allelopathy, Organisms, Processes and Applications. American Chemical Society: Washington, DC; p. 142-157.

Trezzi, M.M., Vidal, R.A., Balbinot, Junior A.A., Bittencourt, H.H., da Silva Souza Filho, A.P. (2016). Allelopathy: driving mechanisms governing its activity in agriculture. Journal of Plant Interactions, 11(1), 53-60. doi:10.1080/17429145.2016.1159342

Vidović, M., Morina, F., Milić, S., Jovanović, S.V. (2015). An improved HPLC-DAD method for simultaneously measuring phenolics in the leaves of Tilia platyphyllos and Ailanthus altissima. Botanica Serbica, 39(2), 177-186.

Vincken, J.P., Heng, L., De Groot, A., Gruppen, H. (2007). Saponins, classification and occurrence in 
the plant kingdom. Phytochemistry, 68, 275-97. doi:10.1016/j.phytochem.2006.10.008

Wagner, H., Bladt, S. (1996). Plant Drug Analysis: A thin layer chromatography atlas. 2nd ed. SpringerVerlag Berlin Heidelberg, Germany; p. 384. doi:10.1007/978-3-642-00574-9

Waller, G.R. (1987). Allelochemicals: role in agriculture and forestry. ACS Symposium Series, 330, American Chemical Society, Washington, D. C. doi:10.1021/bk-1987-0330

Wang, W., Vinocur, B., Altman, A. (2003). Plant responses to drought, salinity and extreme temperatures: towards genetic engineering for stress tolerance. Planta, 218, 1-14. doi:10.1007/s00425003-1105-5

Wender, S.H. (1970). Effects of some environmental stress factors on certain phenolic compounds in tobacco. Recent Advances in Phytochemistry, 3, 129.

Weston, L.A. (2005). History and current trends in the use of allelopathy for weed management. Hort Technology, 15(3), 529-534.

Zhishen, J., Mengcheng, T., Jianming, W. (1999). The determination of flavonoid contents in mulberry and their scavenging effects on superoxide radicals. Food Chemistry, 64, 555-559. doi:10.1016/S03088146(98)00102-2 